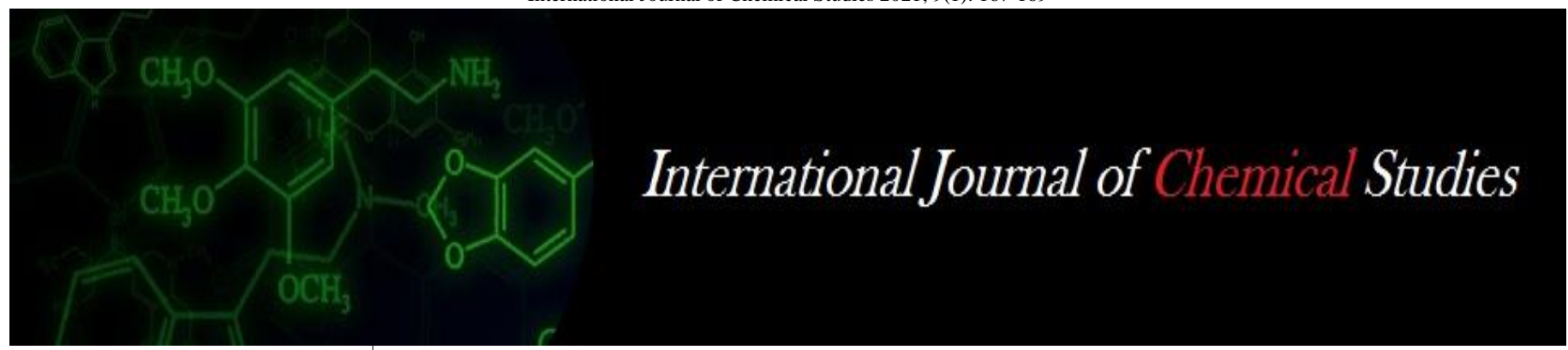

P-ISSN: 2349-8528

E-ISSN: 2321-4902

www.chemijournal.com

IJCS 2021; 9(1): 167-169

(C) 2021 IJCS

Received: 02-10-2020

Accepted: 09-11-2020

\section{TS Shinde}

PG Student, Division of Soil

Science and Agricultural

Chemistry, RCSM, College of

Agriculture, Kolhapur,

Maharashtra, India

\section{Dr. RB Pawar}

Associate Professor, Agriculture

Research Station, Kabse Digraj,

Sangli, Maharashtra, India

AV Satpute

PG Student, Division of

Agronomy, RCSM, College of

Agriculture, Kolhapur,

Maharashtra, India

\section{SM Shende}

PG Student, Division of Agronomy, RCSM, College of Agriculture, Kolhapur,

Maharashtra, India

Corresponding Author: TS Shinde

PG Student, Division of Soil

Science and Agricultural

Chemistry, RCSM, College of

Agriculture, Kolhapur,

Maharashtra, India

\section{Effect of zeolite on chlorophyll content, growth attributing characters and yield of kharif upland paddy grown on Inceptisol}

\author{
TS Shinde, Dr. RB Pawar, AV Satpute and SM Shende
}

DOI: https://doi.org/10.22271/chemi.2021.v9.i1c.11223

\begin{abstract}
A field experiment was conducted in kharif-2019 at Agronomy Farm, Rajarshee Chhatrapati Shahu Maharaj College of Agriculture, Kolhapur. An experiments was laid out in randomized block design with three replications and seven treatments comprising five levels of zeolite $(60,80,100,120$ and $140 \mathrm{~kg}$ ha ${ }^{1}$ ). Application of zeolite significantly increases chlorophyll content of paddy leaves. The highest chlorophyll content $\left(0.84 \mathrm{mg} \mathrm{kg}^{-1}\right.$ and $\left.0.96 \mathrm{mg} \mathrm{kg}^{-1}\right)$ values were recorded with application of zeolite @ $140 \mathrm{~kg} \mathrm{ha}^{-1}\left(\mathrm{~T}_{7}\right)$ at maximum tillering and panicle initiation stage of paddy crop and it was significantly superior over rest of the treatments except $\mathrm{T}_{5}\left(\mathrm{GRDF}+\right.$ Zeolite @ $\left.100 \mathrm{~kg} \mathrm{ha}^{-1}\right)$ and $\mathrm{T}_{6}(\mathrm{GRDF}+$ Zeolite @ $\left.120 \mathrm{~kg} \mathrm{ha}^{-1}\right)$. The significantly highest values of growth parameters and yield attributing characters viz. plant height $(95.67 \mathrm{~cm})$, number of tillers plant ${ }^{-1}(24.33)$, number of panicles (23.33) and 1000 grain weight $(26.11 \mathrm{~g})$ were recorded with application of zeolite @ $140 \mathrm{~kg} \mathrm{ha}^{-1}\left(\mathrm{~T}_{7}\right)$ but it was at par with the treatment T5 (GRDF + Zeolite @ $\left.100 \mathrm{~kg} \mathrm{ha}^{-1}\right)$ and $\mathrm{T}_{6}\left(\mathrm{GRDF}+\right.$ Zeolite @ $120 \mathrm{~kg} \mathrm{ha}^{-1}$ ). There was no significant effect of application of zeolite on number of grains panicle ${ }^{-1}$. The grain and stover yields of paddy increased significantly due to zeolite application. The application of zeolite @ $140 \mathrm{~kg} \mathrm{ha}^{-1}\left(\mathrm{~T}_{7}\right)$ showed significantly the highest grain yield $\left(42.94 \mathrm{q} \mathrm{ha}^{-1}\right)$ and stover yield $\left(59.20 \mathrm{q} \mathrm{ha}^{-1}\right)$ but it was at par with treatment $T_{5}\left(\mathrm{GRDF}+\right.$ Zeolite @ $\left.100 \mathrm{~kg} \mathrm{ha}^{-1}\right)$ and $\mathrm{T}_{6}\left(\mathrm{GRDF}+\right.$ Zeolite @ $\left.120 \mathrm{~kg} \mathrm{ha}^{-1}\right)$ indicating response of zeolite application upto $100 \mathrm{~kg} \mathrm{ha}^{-1}\left(\mathrm{~T}_{5}\right)$. The results of the present investigation indicated that the application of zeolite@ $100 \mathrm{~kg} \mathrm{ha}^{-1}$ along with GRDF was found effective in increasing chlorophyll content, growth attributing characters and yield.
\end{abstract}

Keywords: Chlorophyll content, yield, paddy, clinoptilolite zeolite

\section{Introduction}

The zeolites are hydrated aluminosilicate minerals made from interlinked tetrahedral of alumina $\left(\mathrm{AlO}_{4}\right)$ and silica $\left(\mathrm{SiO}_{4}\right)$. The zeolites are composed of pores and corner sharing aluminosilicate $\left(\mathrm{AlO}_{4}\right.$ and $\left.\mathrm{SiO}_{4}\right)$ tetrahedrons, joined into 3 dimensional frameworks. The pore structure is characterized by cages approximately $12 \AA$ in diameter, which are interlinked through channels about $8 \AA$ in diameter, composed of rings of 12 linked tetrahedrons (Kaduk and Faber, 1995) ${ }^{[2]}$. The zeolite has an ability to gain or lose water reversibly, without the change of crystal structure. They could be used as fertilizers, stabilizers and natural chelates (Perez-Caballero et al., 2008) ${ }^{[5]}$. The zeolite enables both inorganic and organic fertilizers to slowly release their nutrients (Perez-Caballero et al., 2008) ${ }^{[5]}$. The zeolite helps to increase crop yield (Valente et al., 1982) ${ }^{[9]}$

\section{Materials and Methods}

Field experiment was conducted in kharif-2019 on sandy clay loam soil at Agronomy Farm, Rajarshee Chhatrapati Shahu Maharaj College of Agriculture, Kolhapur located at latitude of $16^{0} 42^{\prime}$ North and longitude $74^{0} 14^{\prime}$ East. The field experiment site climatically belongs to SubMontane zone of Maharashtra with an average rainfall of $1057 \mathrm{~mm}$, with 77 rainy days which are received mostly from south-west monsoon. Minimum and maximum mean temperature ranged from 11.83 to $20.9{ }^{\circ} \mathrm{C}$ and 24.9 to $33.1{ }^{\circ} \mathrm{C}$, respectively. The soil of experimental plot was alkaline in reaction ( $\mathrm{pH} 7.83$ ), normal in electrical conductivity $\left(0.17 \mathrm{dS} \mathrm{m}^{-1}\right)$, moderately high in organic carbon content $(0.63 \%)$ and high in $\mathrm{CaCO}_{3}$ content $(9.86 \%)$, and have bulk density $1.27 \mathrm{~g} \mathrm{~cm}^{-3}$, CEC $16.91 \mathrm{cmol}(\mathrm{p}+) \mathrm{kg}^{-1}$. Soil was low in available nitrogen $(171.29 \mathrm{~kg}$ 
$\left.\mathrm{ha}^{-1}\right)$, medium in available phosphorous (16.29 $\left.\mathrm{kg} \mathrm{ha}^{-1}\right)$ and high in available potassium $\left(160.31 \mathrm{~kg} \mathrm{ha}^{-1}\right)$ content sufficient in available $\mathrm{Fe}\left(4.52 \mathrm{mg} \mathrm{kg}^{-1}\right)$, available $\mathrm{Mn}\left(2.04 \mathrm{mg} \mathrm{kg}^{-1}\right)$, available $\mathrm{Zn}\left(1.54 \mathrm{mg} \mathrm{kg}^{-1}\right)$ and available $\mathrm{Cu}\left(1.63 \mathrm{mg} \mathrm{kg}^{-1}\right)$. The experiment was laid out in randomized block design with seven treatments and three replications. The treatments consisted of $\mathrm{T}_{1}$ : Absolute control, $\mathrm{T}_{2}$ : GRDF (100:50:50 kg ha ${ }^{-1} \mathrm{~N}: \mathrm{P}_{2} \mathrm{O}_{5}: \mathrm{K}_{2} \mathrm{O}+$ FYM $\left.10 \mathrm{t} \mathrm{ha}^{-1}\right), \mathrm{T}_{3}:$ GRDF+ Zeolite @ 60 $\mathrm{kg} \mathrm{ha}^{-1}, \mathrm{~T}_{4}$ : GRDF+ Zeolite @ $80 \mathrm{~kg} \mathrm{ha}^{-1}$,

T5: GRDF+Zeolite @ $100 \mathrm{~kg} \mathrm{ha}^{-1}, \mathrm{~T}_{6}$ : GRDF+ Zeolite @ $120 \mathrm{~kg} \mathrm{ha}^{-1}, \mathrm{~T}_{7}$ : GRDF+Zeolite @ $140 \mathrm{~kg} \mathrm{ha}^{-1}$.

The treatment wise application of zeolite and fertilizers mixture was done before sowing of paddy seed and covered with soil. The FYM was applied @ $10 \mathrm{t} \mathrm{ha}^{-1}$.The general recommended dose of fertilizer $\left(100 \mathrm{~kg} \mathrm{~N}+50 \mathrm{~kg} \mathrm{P}_{2} \mathrm{O}_{5}+50\right.$ $\mathrm{kg} \mathrm{K}_{2} \mathrm{O}$ ha $^{-1}$ ) were applied per hectare at the time of sowing as per the treatments.

The variety Indrayani was grown by adopting standard package of practice for the region. The plant height $(\mathrm{cm})$ was measured from ground level by adopting standard procedure at harvest. The number of tillers plant ${ }^{-1}$ and number of panicles plant ${ }^{-1}$ were recorded at harvest from five randomly selected and marked plants and average of five plants was worked out at each observation for comparing treatment effects. The grains obtained after threshing and winnowing of the produce from each net plot were sun dried and their final air dried weight per plot was recorded in $\mathrm{kg}$ and was expressed in $\mathrm{q} \mathrm{ha}^{-1}$. The stover yield per net plot was obtained by weighing the sun dried stover and chaff which remained after removal of grains. It was recorded as stover yield per net plot $(\mathrm{kg})$ and was expressed in $\mathrm{q} \mathrm{ha}^{-1}$. The $4^{\text {th }}$ leaf of plant collected as plant sample at maximum tillering and panical initiation stage for estimation of chlorophyll content from plants. The chlorophyll of fresh plant leaves $\left(4^{\text {th }}\right.$ leaf $)$ collected at tillering stage was extracted in $85 \%$ acetone and the absorbance at $663 \mathrm{~nm}$ and $645 \mathrm{~nm}$ wavelength on spectrophotometer (Arnon, 1949) ${ }^{[1]}$.

\section{Results and Discussion Chlorophyll content}

The data pertaining to chlorophyll content of crop is presented in Table 1. The data clearly indicated that there was significant influence of different treatments on chlorophyll content of paddy. The treatment $\mathrm{T}_{7}$ (GRDF + Zeolite @ 140 $\mathrm{kg} \mathrm{ha} \mathrm{h}^{-1}$ ) applied to paddy registered significantly highest chlorophyll content at maximum tillering and panicle initiation stage of paddy $\left(0.85 \mathrm{mg} \mathrm{kg}^{-1}\right.$ and $\left.0.97 \mathrm{mg} \mathrm{kg}^{-1}\right)$ over all the treatments except $\mathrm{T}_{5}\left(\mathrm{GRDF}+\right.$ Zeolite @ $\left.100 \mathrm{~kg} \mathrm{ha}^{-1}\right)$ and $\mathrm{T}_{6}$ (GRDF + Zeolite @ $\left.120 \mathrm{~kg} \mathrm{ha}^{-1}\right)$. Increase in chlorophyll content at maximum tillering and panicle initiation stage of paddy was observed due to application of zeolite. Chlorophyll coloration is related to the amount of nutrients absorbed by plant from the soil. Chlorophylls have nitrogen structure and zeolite cause increase in efficiency of elements consumption especially nitrogen as well, therefore using zeolite can increase chlorophyll content considerably. Higher chlorophyll content at two stages of paddy observed due to combined effect of GRDF and zeolite application to the field over other treatments.

The results are close conformity with the findings reported by Majid et al. (2012), Shahsavari et al. (2014), Shahrzad Alfi and Farhad Azizi (2015) ${ }^{[3,8,7]}$.

Table 1: Chlorophyll content in $4^{\text {th }}$ leaf of paddy at maximum tillering and panicle initiation stage as influenced by different levels of zeolite

\begin{tabular}{|c|c|c|c|}
\hline \multirow{2}{*}{ Tr. No. } & \multirow{2}{*}{ Treatment Details } & \multicolumn{2}{|c|}{ Chlorophyll content $\left(\mathrm{mg} \mathrm{g}^{-1}\right)$ in $4^{\text {th }}$ leaf of paddy } \\
\hline & & Maximum tillering stage & Panicle initiation stage \\
\hline $\mathrm{T}_{1}$ & Absolute control & 0.51 & 0.55 \\
\hline $\mathrm{T}_{2}$ & GRDF (100:50:50 kg ha- $\left.{ }^{-1} \mathrm{~N}: \mathrm{P}_{2} \mathrm{O}_{5}: \mathrm{K}_{2} \mathrm{O}+\mathrm{FYM} 10 \mathrm{t} \mathrm{ha}^{-1}\right)$ & 0.59 & 0.66 \\
\hline $\mathrm{T}_{3}$ & GRDF+Zeolite@60 kg ha ${ }^{-1}$ & 0.69 & 0.76 \\
\hline $\mathrm{T}_{4}$ & GRDF+ Zeolite@ $@ 80 \mathrm{~kg} \mathrm{ha}^{-1}$ & 0.76 & 0.86 \\
\hline $\mathrm{T}_{5}$ & GRDF+Zeolite @ $100 \mathrm{~kg} \mathrm{ha}^{-1}$ & 0.83 & 0.95 \\
\hline $\mathrm{T}_{6}$ & GRDF + Zeolite @ $120 \mathrm{~kg} \mathrm{ha}^{-1}$ & 0.84 & 0.96 \\
\hline $\mathrm{T}_{7}$ & GRDF + Zeolite@140 kg ha ${ }^{-1}$ & 0.84 & 0.96 \\
\hline \multicolumn{2}{|r|}{ SE \pm} & 0.02 & 0.03 \\
\hline \multicolumn{2}{|r|}{$\mathrm{CD}(0.05)$} & 0.07 & 0.08 \\
\hline
\end{tabular}

\section{Growth and yield attributing characters}

The data pertaining to growth and growth parameter are presented in Table 4.4. The data clearly indicated that there was significant influence of GRDF alone and with different levels of zeolite on growth and growth parameters of paddy.

In case of plant height, it was observed that the treatment $\mathrm{T}_{7}$ (GRDF+ Zeolite @ $140 \mathrm{~kg} \mathrm{ha}{ }^{-1}$ ) registered significantly highest plant height $(95.67 \mathrm{~cm})$ over all the treatments except $\mathrm{T}_{5}\left(\mathrm{GRDF}+\right.$ Zeolite @ $\left.100 \mathrm{~kg} \mathrm{ha}^{-1}\right)$ and $\mathrm{T}_{6}(\mathrm{GRDF}+$ Zeolite @ $120 \mathrm{~kg} \mathrm{ha}^{-1}$ ).

The significantly highest number of tillers per plant (24.33) were observed with the treatment $\mathrm{T}_{7}(\mathrm{GRDF}+$ Zeolite @ 140 $\left.\mathrm{kg} \mathrm{ha}^{-1}\right)$, however it was at par with $\mathrm{T}_{5}(\mathrm{GRDF}+$ Zeolite @ $\left.100 \mathrm{~kg} \mathrm{ha}^{-1}\right)$ and $\mathrm{T}_{6}\left(\right.$ GRDF + Zeolite @ $\left.120 \mathrm{~kg} \mathrm{ha}^{-1}\right)$.

The significantly highest number of panicles per plant (23.33) were recorded with the treatment $\mathrm{T}_{7}(\mathrm{GRDF}+$ Zeolite @ 140 $\left.\mathrm{kg} \mathrm{ha}^{-1}\right)$ but it was at par with $\mathrm{T}_{5}(\mathrm{GRDF}+$ Zeolite @ $100 \mathrm{~kg}$ $\left.\mathrm{ha}^{-1}\right)$ and $\mathrm{T}_{6}\left(\mathrm{GRDF}+\right.$ Zeolite @ $\left.120 \mathrm{~kg} \mathrm{ha}^{-1}\right)$.

The treatment $\mathrm{T}_{7}\left(\mathrm{GRDF}+\right.$ Zeolite @ $\left.140 \mathrm{~kg} \mathrm{ha}^{-1}\right)$ recorded significantly highest 1000 grain weight of paddy crop (26.11g), however it was at par with, $\mathrm{T}_{5}(\mathrm{GRDF}+$ Zeolite @ $100 \mathrm{~kg} \mathrm{ha}^{-1}$ ) and $\mathrm{T}_{6}\left(\mathrm{GRDF}+\right.$ Zeolite @ $\left.120 \mathrm{~kg} \mathrm{ha}^{-1}\right)$.

The number of grains panicle ${ }^{-1}$ were not influenced significantly due to different treatments.

The increase in plant height, number of tillers, number of panicles and 1000-grain weight of paddy due to application of fertilizer alongwith different levels of zeolite might be due to favourable effect of zeolites in increasing the nutrient use efficiency of paddy. These results are in accordance with those reported by Mevlut et al. (2006), Sembiring et al. (2017), Walundari et al. (2019) ${ }^{[4,6] .}$ 
Table 2: Effect of zeolite application on growth and yield attributing characters of paddy at harvest as influenced by different levels of zeolite

\begin{tabular}{|c|c|c|c|c|c|c|}
\hline \begin{tabular}{|l|} 
Tr. \\
No.
\end{tabular} & Treatment Details & $\begin{array}{c}\text { Plant height } \\
\text { (cm) }\end{array}$ & $\begin{array}{c}\text { No. of tillers } \\
\text { plant }^{-1}\end{array}$ & \begin{tabular}{|c|} 
No. of panicles \\
plant $^{-1}$
\end{tabular} & $\begin{array}{c}\text { No. of grains } \\
\text { panicle }^{-1}\end{array}$ & $\begin{array}{c}1000 \text { grain } \\
\text { weight }(\mathrm{g})\end{array}$ \\
\hline $\mathrm{T}_{1}$ & Absolute control & 62.33 & 13.00 & 11.67 & 84.67 & 17.65 \\
\hline $\mathrm{T}_{2}$ & GRDF (100:50:50 kg ha $\left.{ }^{-1} \mathrm{~N}: \mathrm{P}_{2} \mathrm{O}_{5}: \mathrm{K}_{2} \mathrm{O}+\mathrm{FYM} 10 \mathrm{t} \mathrm{ha}^{-1}\right)$ & 69.67 & 15.89 & 15.00 & 88.00 & 19.61 \\
\hline \begin{tabular}{|l|l}
$\mathrm{T}_{3}$ \\
\end{tabular} & GRDF+Zeolite @ $60 \mathrm{~kg} \mathrm{ha}^{-1}$ & 77.00 & 17.98 & 17.50 & 90.33 & 21.81 \\
\hline $\mathrm{T}_{4}$ & GRDF+Zeolite@80 kg ha ${ }^{-1}$ & 84.00 & 20.51 & 20.00 & 92.00 & 23.85 \\
\hline \begin{tabular}{|l|l}
$\mathrm{T}_{5}$ \\
\end{tabular} & GRDF+Zeolite @ $100 \mathrm{~kg} \mathrm{ha}^{-1}$ & 91.00 & 22.60 & 22.33 & 95.67 & 25.81 \\
\hline \begin{tabular}{|l|l}
$\mathrm{T}_{6}$ \\
\end{tabular} & GRDF + Zeolite@120 kg ha ${ }^{-1}$ & 93.33 & 23.30 & 22.67 & 96.67 & 25.96 \\
\hline \begin{tabular}{|l|}
$\mathrm{T}_{7}$ \\
\end{tabular} & GRDF + Zeolite @ $140 \mathrm{~kg} \mathrm{ha}^{-1}$ & 95.67 & 24.33 & 23.33 & 97.67 & 26.11 \\
\hline & $\mathrm{SE} \pm$ & 2.20 & 0.61 & 0.58 & 3.74 & 0.61 \\
\hline & $\mathrm{CD}(0.05)$ & 6.79 & 1.88 & 1.78 & NS & 1.89 \\
\hline
\end{tabular}

\section{Yield}

The data pertaining to yield and yield contributing characters are presented in Table 3. The data clearly indicated that there was significant influence of different treatments on grain yield and stover yield of paddy. The treatment $\mathrm{T}_{7}(\mathrm{GRDF}+$ Zeolite (a) $140 \mathrm{~kg} \mathrm{ha}^{-1}$ ) recorded significantly highest grain yield and stover yield (42.94 q ha-1 and $59.20 \mathrm{q} \mathrm{ha}^{-1}$ ) over all the treatments except $\mathrm{T}_{5}\left(\mathrm{GRDF}+\right.$ Zeolite @ $\left.100 \mathrm{~kg} \mathrm{ha}^{-1}\right)$ and $\mathrm{T}_{6}$ (GRDF + Zeolite @ $\left.120 \mathrm{~kg} \mathrm{ha}^{-1}\right)$ indicating favourable effect of zeolite upto $100 \mathrm{~kg} \mathrm{ha} \mathrm{ha}^{-1}$ along with GRDF. The significantly higher yield and yield parameters of the paddy crop were recorded due to combined effect of GRDF and zeolite application to the field than the treatment with only GRDF to the crop.

The increase in grain yield and stover yield due to zeolite application to paddy might be due to constant steady supply of nutrient throughout the crop growth period. The zeolite with honeycomb structure acts as a store house of macro and micronutrients. Zeolite with permanent negative charge is responsible for adsorption of nutrient cations and their subsequent release by ion exchange throughout the growth period of paddy. Improvement in nutrient use efficiency by increasing the availability and uptake of some macronutrients and micronutrients led to increase yield of paddy. Also zeolite has positive effect on physical and chemical properties of soil like higher available water holding and high adsorption capacities which helps to increase the yield.

Similar beneficial effect of zeolite reported by Mevlut et al. (2006) ${ }^{[4]}$, Sepaskhah and Barzegar (2010), Ozbahce et al. (2015), Qi et al. (2016), Junlin et al. (2018).

Table 3: Grain and stover yield of paddy as influenced by different levels of zeolite

\begin{tabular}{|c|c|c|c|}
\hline Tr. No. & Treatments details & Grain yield $\left(\mathrm{q} \mathrm{ha}^{-1}\right)$ & Stover yield $\left(\mathrm{q} \mathrm{ha}^{-1}\right)$ \\
\hline $\mathrm{T}_{1}$ & Absolute control & 12.83 & 17.31 \\
\hline $\mathrm{T}_{2}$ & 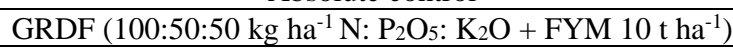 & 31.54 & 41.34 \\
\hline $\mathrm{T}_{3}$ & GRDF+Zeolite @ $60 \mathrm{~kg} \mathrm{ha}^{-1}$ & 35.49 & 46.71 \\
\hline $\mathrm{T}_{4}$ & GRDF+Zeolite@80 kg ha-1 & 38.68 & 52.59 \\
\hline $\mathrm{T}_{5}$ & GRDF+Zeolite @ $100 \mathrm{~kg} \mathrm{ha}^{-1}$ & 41.86 & 58.00 \\
\hline $\mathrm{T}_{6}$ & GRDF + Zeolite @ $120 \mathrm{~kg} \mathrm{ha}^{-1}$ & 42.21 & 58.23 \\
\hline $\mathrm{T}_{7}$ & GRDF + Zeolite@140 kg ha ${ }^{-1}$ & 42.94 & 59.20 \\
\hline \multicolumn{2}{|r|}{ SE \pm} & 1.02 & 1.67 \\
\hline \multicolumn{2}{|r|}{$\mathrm{CD}(0.05)$} & 3.16 & 5.16 \\
\hline
\end{tabular}

\section{References}

1. Arnon DI. Copper enzymes in isolated chloroplasts polyphenol oxiasen in Beta vulgaris. Plant Physiology 1949;24:1-15.

2. Kaduk JA, Faber J. Crystal structure of zeolite as a function of ion exchange. RIGAKU Journal 1995;12(2):14-34.

3. Majid Bahadoran, Hassan Salehi, Saeid Eshghi. Growth and flowering of tuberose as affected by adding natural zeolite to the culture medium. Journal of Plant Nutrition 2012a;35:1491-1496.

4. Mevlut Turk, Gamze Bayram, Emine Budakli, Necmettin Celik. A study on effect of different mixtures of zeolite with soil rates on some yield parameters of alfalfa. Journal of Agronomy 2006;5(1):118-121.

5. Perez-Caballero R, Gil J, Benitez C, Gonzalez JL. Effect of adding zeolite to soils in order to improve the N-K nutrition of olive trees, preliminary results. American Journal of Agriculture Biological Science 2008;2(1):321324.

6. Sembiring S, Sembiring R, Karo SR. Zeolite and urea fertilizer in the growth and yield of maize. Journal of Research in Agriculture and Animal Science 2017;4(9):14-24.
7. Shahrzad Alfi, Farhad Azizi. Effect of drought stress and using zeolite on some quantitative and qualitative traits of three maize varieties. Research Journal of Recent Science 2015;4(2):1-7.

8. Shahsavari N, Mohd H, Rad A. Effect of zeolite and zinc on the biochemical characteristics of canola upon drought stress. Sains Malaysiana 2014;43:1549-1555.

9. Valente S, Burriesci N, Cavallaro S, Galvagno S, Zipelli C. Utilization of zeolites as soil conditioner in tomatogrowing. Zeolites 1982;2:271-274.

10. Wulandari R, Hanum H, Hasanah Y. The effect of nitrogen fertilizer, zeolite and fresh straw to increase total-N, cation exchange capacity (CEC) of rice crop. Conference Series: Earth and Environmental Science 2019;260:1-5. 